DOI: $10.17516 / 1997-1370-0557$

УДК 378.017 .92

\title{
Spiritual Modernisation of Student Youth
}

\author{
Bakhytgul A. Zhetpisbayevaa, Zhanbol O. Zhilbayev', \\ Lyailya S. Syrymbetovaa , Dmitry V. Dyakova \\ and Laura M. Muratovac \\ ${ }^{a}$ Innovative University of Eurasia \\ Pavlodar, Kazakhstan \\ ${ }^{b}$ National Academy of Education named after Y. Altynsarin \\ Nur-Sultan, Kazakhstan \\ ${ }^{c}$ Karaganda State University named after academician E.A. Buketov \\ 28 University St., Karaganda, 100028, Kazakhstan
}

Received 17.01.2020, received in revised form 20.01.2020, accepted 11.02.2020

\begin{abstract}
The article is devoted to the problem of implementing the national programme for the spiritual revival of Kazakhstani society. Based on empirical data, the authors of the article analyse the degree to which students develop spiritual values of the programme and substantiate the role of the pedagogical community in developing mechanisms for its implementation. The authors conclude that most students are aware of the provisions of the programme, but have not made them part of their system of values, life goals, and attitudes. In the context of this, the authors offer their own conceptual approach to the issue of implementing the programme in the conditions of Kazakhstani universities.
\end{abstract}

Keywords: spiritual revival of society, modernisation of consciousness, values, social portrait, students, academic community, Kazakhstan, Kazakhstani, the concept of promoting values.

Research area: education.

Citation: Zhetpisbayeva, B.A., Zhilbayev, Z.O., Syrymbetova, L.S., Dyakov, D.V., Muratova, L.M. (2020). Spiritual modernisation of student youth. J. Sib. Fed. Univ. Humanit. Soc. Sci., 13(2), 258-267. DOI: $10.17516 / 1997-1370-0557$.

(C) Siberian Federal University. All rights reserved

* Corresponding author E-mail address: zh.64@mail.ru, miss.syrymbetova@mail.ru ORCID: 0000-0002-1528-4494 (Zhetpisbayeva); 0000-0003-1868-1142 (Zhilbayev); 0000-0002-5063-3231 (Syrymbetova); 0000-0001-6113-6065 (Dyakov); 0000-0001-8196-4431 (Muratova) 


\section{Introduction}

to the research problem

Today Kazakhstan is implementing the Third Modernisation, the essence of which is the spiritual revival of society. This idea was presented in a programmatic article by the First President of Kazakhstan, Nursultan Nazarbayev, "A look into the future: the modernisation of public consciousness" (Nazarbayev, 2017). According to the author of the idea, each Kazakhstani citizen, while maintaining his national identity, must successfully and adequately integrate into the world community. In other words, one should live in a global world being a patriot of your country. To solve this difficult task, 6 principles are formulated:

1. Competitiveness;

2. Pragmatism;

3. National identity;

4. Cult of knowledge;

5. Evolutionary rather than revolutionary development;

6. Open mind.

Following these principles will allow to form a new generation of Kazakhstanis, who possess a number of vital qualities in the $21^{\text {st }}$ century:

- be highly educated, know foreign languages, be fluent in information technology, be able to learn throughout life;

- strive for professional success, be able to change a profession;

- lead a healthy lifestyle, be rational, be able to withstand projection, populism, wastefulness;

- understand what is happening in the country and the world, adopt the best experience, be able to learn from others;

- be able to create and contribute to the prosperity of society;

- be aware of their belonging to the single people of Kazakhstan, to be tolerant of dissent.

The advantage of the national programme for the modernisation of public consciousness, known as the "Ruhani Zhangyru" Programme, is systematicity, continuity and complexity.

The Programme is consistent while its conceptual part is accompanied by six basic projects aimed at the practical implementation of the above principles:

1. "A phased transfer of the Kazakh language into Latin graphics".

2. "New humanitarian knowledge. 100 new textbooks in the Kazakh language".

3. "Tugan zher" (Native land).

4. "Sacred geography of Kazakhstan".

5. "Modern Kazakhstani culture in the global world".

6. "100 new faces of Kazakhstan".

Continuity is expressed in the fact that this Programme is a logical continuation of the national idea "Mangilik El" (Eternal Nation), which is based on the concept of Kazakh patriotism (Poslanie..., 2012). Emerging from this idea, the programme "Ruhani Zhangyru" became the forerunner of the programme article by N. Nazarbayev "Seven faces of the Great Steppe" (Nazarbayev, 2018).

The complex nature of the Programme is manifested in the fact that it combines 4 subprogrammes and 12 special projects (Table 1).

Given the socio-humanitarian focus of the Programme, the academic community of Kazakhstan sees itself as the main translator of its values. In this regard, the problem of determining ways, developing mechanisms for promoting the Programme in the educational environment arises: in a preschool organisation, school, college, university. It is important to take into account the multistructured educational environment, which, in addition to teachers and students, includes a wide range of external participants: parents, employers, social and political organisations, government agencies, etc.

During the two years of the Programme implementation, an understanding of its main provisions, goals and objectives took place. Certain experience has been gained in explaining and popularising its values. At this stage of the programme development, it is necessary, in our opinion, to develop specific strategies and tactics for its promotion in society.

\section{Theoretical framework}

The starting point of our study is the goal of scientific understanding of state approaches to the problems of adaptation of Kazakhstani 
Table 1. "Ruhani Zhangyru" Programme matrix

\begin{tabular}{|c|c|c|c|c|}
\hline $\begin{array}{c}\text { SPECIAL } \\
\text { PROJECTS }\end{array}$ & $\begin{array}{l}\text { Subprogramme } \\
\text { "Parenting and } \\
\text { education" }\end{array}$ & $\begin{array}{l}\text { Subprogramme } \\
\text { "Fatherland" }\end{array}$ & $\begin{array}{l}\text { Subprogramme } \\
\text { "Spiritual heritage" }\end{array}$ & $\begin{array}{l}\text { Subprogramme } \\
\text { "Information- } \\
\text { al support" }\end{array}$ \\
\hline TUGAN ZHER & $\begin{array}{l}\text { Local history; } \\
\text { My Homeland } \\
\text { is my destiny; } \\
\text { Conscious Citizen, } \\
\text { Book as a Source } \\
\text { of Knowledge }\end{array}$ & $\begin{array}{l}\text { Map of local } \\
\text { initiatives; } \\
\text { Generous heart }\end{array}$ & $\begin{array}{l}\text { Regional cul- } \\
\text { ture, traditions } \\
\text { and values; } \\
\text { Domestic and } \\
\text { pilgrim tourism }\end{array}$ & \multirow{4}{*}{ 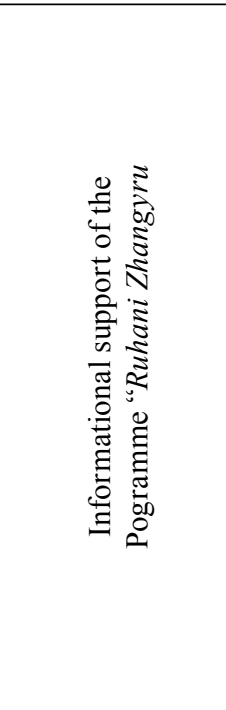 } \\
\hline $\begin{array}{l}\text { SACRED GE- } \\
\text { OGRAPHY }\end{array}$ & \multicolumn{2}{|c|}{ Tasks of other Base Projects } & $\begin{array}{c}\text { National val- } \\
\text { ues - the unity of } \\
\text { the people; Noble } \\
\text { generation; } \\
\text { Sacred Kazakhstan }\end{array}$ & \\
\hline $\begin{array}{c}\text { KAZAKHSTANI } \\
\text { CULTURE IN } \\
\text { MODERN } \\
\text { WORLD }\end{array}$ & \multicolumn{2}{|c|}{ Tasks of other Base Projects } & $\begin{array}{l}\text { Cultural de- } \\
\text { velopment }\end{array}$ & \\
\hline $\begin{array}{c}100 \text { NEW } \\
\text { TEXTBOOKS }\end{array}$ & $\begin{array}{l}\text { New humanitarian } \\
\text { knowledge. } 100 \text { new } \\
\text { textbooks in Kazakh }\end{array}$ & ---- & $\begin{array}{l}\text { Tasks of other } \\
\text { Base Projects }\end{array}$ & \\
\hline 100. NEW FACES & \multicolumn{3}{|c|}{ Tasks of other Base Projects } & 100 new faces \\
\hline $\begin{array}{c}\text { TRANSFER } \\
\text { OF THE } \\
\text { KAZAKH } \\
\text { LANGUAGE INTO } \\
\text { LATIN } \\
\text { GRAPHICS }\end{array}$ & $\begin{array}{c}\text { Transfer of the } \\
\text { Kazakh language } \\
\text { into Latin graphics }\end{array}$ & ----- & \multicolumn{2}{|c|}{ Tasks of other Base Projects } \\
\hline
\end{tabular}

society in the context of cultural globalisation. We believe that the gravitational vector of the Programme is aimed at implementing a creative scenario for the development of mankind, i.e. a global dialogue of cultures. A conceptual understanding of this will allow us to build a policy for promoting this Programme in the system of national education. Our research was based on such concepts as "Social Values", "Value Attitudes", "Modernisation", "Public Consciousness" and "Spiritual Revival". In our opinion, all these concepts, being parallel, are understood as a pedagogical tools for the formation of Kazakhstani content of educational programmes of schools, colleges and universities.

\section{Statement of the problem}

The modern academic community of Kazakhstan is facing the problem of formal, fragmented execution of the Programme in the framework of official directives. Initiatives to implement the Programme belong primarily to the state and municipal authorities. Until now, the academic community has not developed its own systemic mechanisms that would fully integrate the Programme's value orientations into the content of Kazakhstani education. We believe that the leading role in solving the existing problem should belong to higher educational institutions. Their potential allows us to offer scientifically based mechanisms for introducing the programme's value orientations into textbooks, curricula, and methodological instructions for all educational levels.

\section{Methods}

In the framework of our study, we studied empirical data on the degree of awareness of students of various universities in Kazakhstan 
Table 2. Respondent Information

\begin{tabular}{|c|c|c|c|}
\hline $\begin{array}{c}\text { Conventional name } \\
\text { of the university }\end{array}$ & $\begin{array}{c}\text { Total number of 1-3 } \\
\text { courses students }\end{array}$ & Number of respondents & $\begin{array}{c}\text { Proportion } \\
\text { of surveyed students (\%) }\end{array}$ \\
\hline A & 310 & 101 & 33 \\
\hline B & 437 & 123 & 28 \\
\hline C & 272 & 87 & 32 \\
\hline D & 671 & 206 & 31 \\
\hline E & 221 & 68 & 31 \\
\hline Total & $\mathbf{1 , 9 1 1}$ & $\mathbf{5 8 5}$ & $\mathbf{3 1}$ \\
\hline
\end{tabular}

about the content of the Programme, their relationship to value attitudes. This allowed us to identify trends, evaluate them, identify problems and identify ways to solve them. In this regard, we conducted a survey of students, the results of which were subjected to mathematical processing, compiled a comparative analysis of the data. On this basis we developed the concept of promoting the value orientations of the "Ruhani Zhangyru" Programme in the student community.

Students of five leading universities from different regions of Kazakhstan doing their $2^{\text {nd }}$ $3^{\text {rd }}$ year of studies took part in the survey. The amount of respondents covered $31 \%$ of the total amount of students, which ensures representativeness of the sample (Table 2).

The developed questionnaire contained 10 questions aimed at identifying the level of solidarity of students with the main provisions of the Programme and its impact on the students' value system related to education, competitive- ness, pragmatism, openness of consciousness, preservation of national identity, vision of the evolutionary development of Kazakhstan.

\section{Discussion}

As the survey showed, only one third of the respondents have an idea of the contents of the Programme (Fig. 1). This indicates that the work carried out in the universities under study to promote the values of spiritual revival should be strengthened.

Judging by the answers received, the students showed the greatest awareness regarding the project "Transfer of the Kazakh language into Latin graphics" (60\%). For other projects, a different picture is observed. Thus, $35 \%$ of respondents are well informed about the project "100 New Faces of Kazakhstan"; 28\% about the project "New humanitarian knowledge. 100 new textbooks in the Kazakh language"; $25.5 \%$ about "Sacred Geography of Kazakhstan"; 23.5\% about "Tugan Zher"; 19\% about

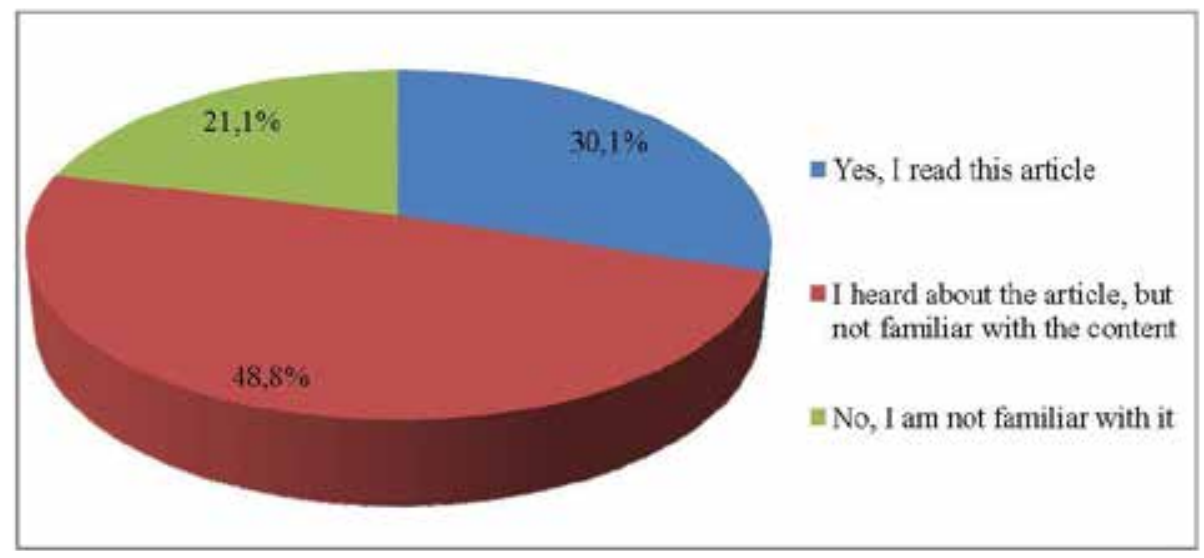

Fig. 1. The degree of students' awareness of the Programme 
"Modern Kazakhstan culture in the global world" (Table 3).

The prevailing ratio shows that the students are least aware of the project "Modern Kazakhstan culture in the global world". This indicates the cultural isolation of the vast majority of students surveyed. We assume that the reason for this is the weak focus of training programmes on expanding the worldview and developing global thinking among young Kazakhstanis. This confirms the timeliness of the proclamation of the "Open Mind" principle.

Most students (61\%) believe that knowledge of the projects of the Programme contributes to changes in the public consciousness of Kazakhstanis. $20 \%$ of respondents do not agree with this statement; $19 \%$ do not know anything about these projects (Fig. 2). Taking into ac- count the opinion of most students, we note a positive tendency to realise the importance of the Programme.

More than $60 \%$ of students recognise the universal value of higher education, which is a competitive factor. For the rest of the respondents (39\%), this is just one of the tools to achieve social success (Fig. 3). In this context, it can be argued that most students are committed to the value of the cult of knowledge.

During the survey, students were asked to rank 6 factors of personality competitiveness by degree of importance. The answers received show that the most significant for students are their ability to work, aspiration for professional growth $(46.5 \%)$; stress resistance, ability to overcome difficulties (36\%); sociability, ability to cooperate $(31.8 \%)$.

Table 3. Student Awareness of Projects Implemented by the "Ruhani Zhangyru" Programme

\begin{tabular}{|l|c|c|c|}
\multicolumn{1}{|c|}{ Projects } & $\begin{array}{c}\text { I know } \\
\text { about it }\end{array}$ & $\begin{array}{c}\text { I heard } \\
\text { something }\end{array}$ & $\begin{array}{c}\text { I know } \\
\text { nothing }\end{array}$ \\
\hline "Transfer of the Kazakh language into Latin graphics" & $60 \%$ & $34 \%$ & $6 \%$ \\
\hline $\begin{array}{l}\text { "New humanitarian knowledge. 100 new text- } \\
\text { books in the Kazakh language" }\end{array}$ & $28 \%$ & $43 \%$ & $29 \%$ \\
\hline "Tugan Zher" Programme & $24 \%$ & $34 \%$ & $42 \%$ \\
\hline $\begin{array}{l}\text { "Spiritual Shrines of Kazakhstan" or "Sa- } \\
\text { cred Geography of Kazakhstan" }\end{array}$ & $26 \%$ & $32 \%$ & $42 \%$ \\
\hline "Modern Kazakhstan culture in the global world" & $19 \%$ & $36 \%$ & $45 \%$ \\
\hline "100 New Faces of Kazakhstan" & $35 \%$ & $39 \%$ & $26 \%$ \\
\hline
\end{tabular}

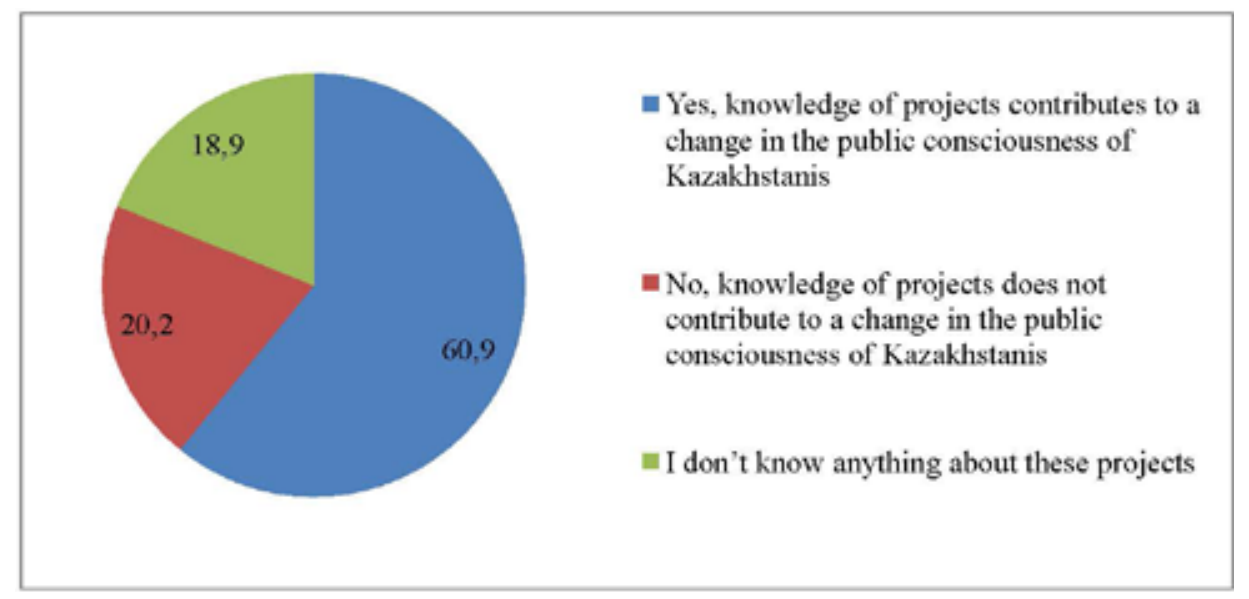

Fig. 2. Students' opinions on projects 


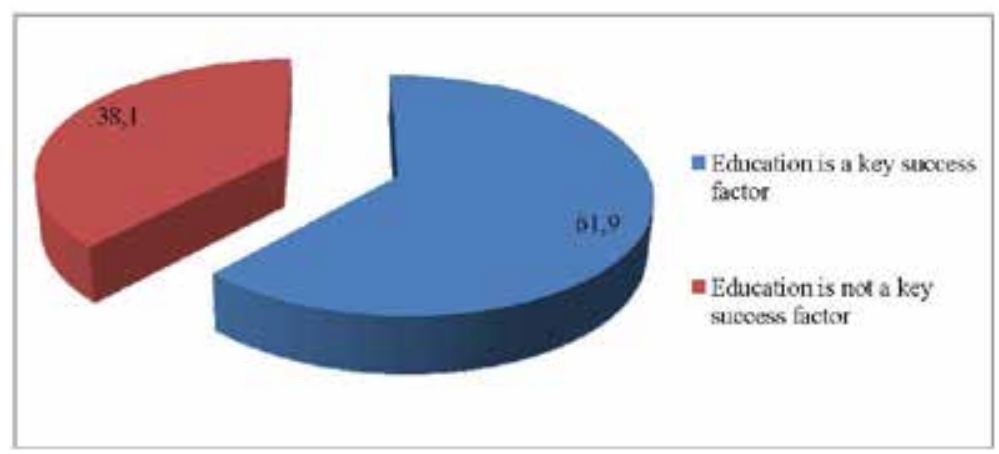

Fig. 3. The opinion of students about higher education

As can be seen from the response statistics, most students do not consider the personality qualities indicated in Table 4 as competitive factors. This situation reflects a tendency to misunderstand the importance of soft skills for life in the modern world: the VUCA world (Chto takoe VUCA..., 2016; Mir VUCA..., 2016; Chukhniu, 2016).

Moreover, most students show a high level of pragmatism in their judgments. This applies to respect for nature and the environment $(98 \%)$, achievement of goals in view of one's capabilities (94\%), academic success $(85 \%)$, and healthy living (78\%). This may indicate the presence of rational thinking and a sufficient level of social responsibility of most students (Table 5).

Despite the positive trend, there is an inability to correlate their positive aspirations with the need to develop soft skills. This contradiction reinforces our assumption about the relevance of developing systemic mechanisms for the socialisation of student youth.

Half of the students surveyed indicated that they are positioning themselves as $\mathrm{Ka}$ zakhstanis, this indicates their civic maturity. Every third respondent (31\%) notes that they are primarily citizens of the world, $11 \%$ indicated their biological status ("male"), $2 \%$ - nationality, $1 \%$ - religious identity (Fig. 4).

Table 4. The degree of importance of competitiveness factors for students

\begin{tabular}{|l|c|}
\hline \multicolumn{1}{|c|}{ Competitiveness factors } & Degree of importance (\%) \\
\hline 1. Ability to work, aspiration for professional growth & $46.5 \%$ \\
\hline 2. Stress resistance, ability to overcome difficulties & $36.7 \%$ \\
\hline 3. Sociability, ability to cooperate & $31.8 \%$ \\
\hline 4. Timely achievement of the final result & $27.1 \%$ \\
\hline 5. Computer literacy & $26.3 \%$ \\
\hline 6. Knowledge of foreign languages & $25.1 \%$ \\
\hline
\end{tabular}

Table 5. Aspirations of students

\begin{tabular}{|l|c|c|}
\hline \multicolumn{1}{|c|}{ Aspirations } & Typical & Not typical \\
\hline 1. I try to achieve my goals according to my capabilities & $94 \%$ & $6 \%$ \\
\hline 2. I lead a healthy lifestyle & $78 \%$ & $22 \%$ \\
\hline 3. I try to be successful in my studies & $85 \%$ & $15 \%$ \\
\hline 4. I take care of nature, ecology & $98 \%$ & $2 \%$ \\
\hline
\end{tabular}




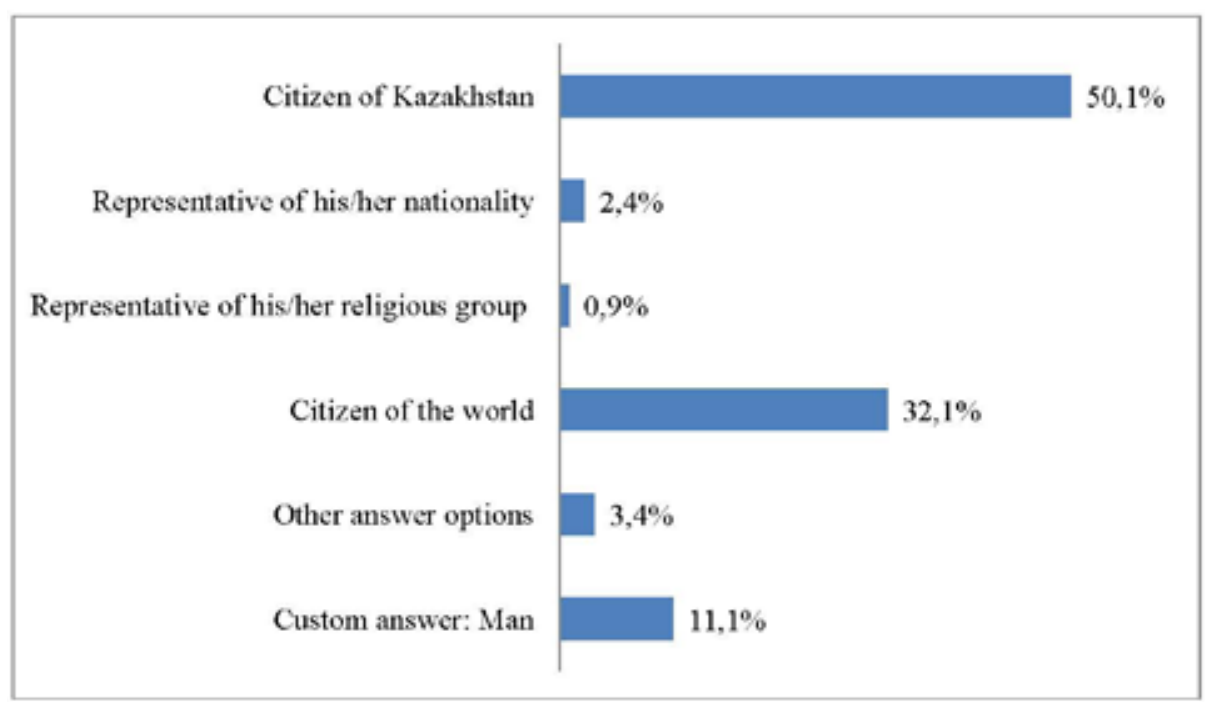

Fig. 4. Students' Identity

Despite the ambiguity of the existing picture, in our opinion, the lack of a holistic view of the Kazakhstani people as an established social category is obvious. At the same time, there is no reason to consider this as manifestation of radicalism (Smolyaninova, Bezyzvestnykh, 2016). It is rather a consequence of an unbalanced cultural paradigm that originated in the transitional conditions of the 90s. The "Ruhani Zhangyru" programme is aimed at understanding the importance of restoring balance was.

The vast majority of students surveyed choose the evolutionary path for the development of Kazakhstan, which is caused by such factors as improving the quality of education and health care (44\%), eradicating corruption (44\%), developing science and technology $(42 \%)$, educating a free personality $(27 \%)$. It is important to note that the absolute minority of respondents shows protest moods: $2-6 \%$ (Table 6). In this, in our opinion, the healthy foundation of the Kazakhstani society is able to accept the values of the Programme.

In general, the results of the survey showed a heterogeneous picture of students' involvement in the values of the Programme. Most students share the ideological message of the "Ruhani Zhangyru" Programme, but at the same time demonstrate detachment from its specific value orientations. In our opin-

Table 6. Factors contributing to the progressive development of Kazakhstan

\begin{tabular}{|l|c|}
\hline \multicolumn{1}{|c|}{ Factors } & Students' Opinion (\%) \\
\hline 1. Improving the quality of education and health care & $44 \%$ \\
\hline 2. Eradication of corruption & $44 \%$ \\
\hline 3. Science and technology development & $42 \%$ \\
\hline 4. Educating a free personality & $27 \%$ \\
\hline 5. Industry and infrastructure development & $19 \%$ \\
\hline 6. Civil society development & $13 \%$ \\
\hline 7. Democratic institutions development & $9 \%$ \\
\hline 8. Protest movements & $6 \%$ \\
\hline 9. Opposition parties' activities & $2 \%$ \\
\hline
\end{tabular}


ion, this is due to the fact that many students perceive the proposed projects as something mandatory not for them, but for other people. The change in the situation can be facilitated by professional support from teachers in the formation of students' social experience to project the ideas of the Programme on a personal value system.

Based on the results of the survey, we propose the Concept of promoting the values of the "Ruhani Zhangyru" national programme in the student community. This Concept is designed to create a holistic picture, clearly define the goal and objectives, as well as update a specific set of principles. Therefore, the goal of promoting the values of the Programme at the university is to create the necessary conditions for involving the vast majority of students and university staff in the processes of modernisation of public consciousness. This goal, in our opinion, is realistic, achievable and measurable.

The following tasks are defined as stepby-step actions to achieve the goal:

- analysis, clarification and popularisation of ideas voiced in the articles "A look into the future: the modernisation of public consciousness" and "Seven Facets of the Great Steppe";

- scientific and methodological interpretation of the historical essence and significance of the ideas of "Ruhani Zhangyru";

- scientific and methodological support for the implementation of the ideas and programme areas of "Ruhani Zhangyru";

- introduction of the educational foundations of spiritual modernisation into the educational and research activities of the university.

To solve these problems the following provisions have been adopted as principles:

1) the transition from one-time events to long-term social projects, i.e. if traditional one-time events are expediently maintained, the promotion of the "Ruhani Zhangyru" will be carried out as part of long-term projects (for a period of one to three months) involving the maximum number of students and employees of the university;

2) access to the external environment, which means that a wide range of external par- ticipants will be involved in the implementation of major events and, above all, long-term projects. This is, first of all, the parent community, friends and relatives of students and employees, applicants, domestic and foreign partners of the university, including other educational organisations, industrial enterprises, public organizations, etc.;

3) the integration of the values of "Ruhani Zhangyru" into educational programmes and research work, this means synchronisation of the content of individual academic disciplines, topics of dissertations, master's theses, scientific studies of scientists with ideas of modernisation of public consciousness.

The details of the proposed Concept should be reflected in a special document, for example, an Action Plan related to the objectives of the Concept. Therefore, we propose highlighting such sections as:

1) scientific and methodological provision for the implementation of the ideas of " $\mathrm{Ru}$ hani Zhangyru";

2) scientific and methodological support for the implementation of the ideas of "Ruhani Zhangyru";

3) social projects of the university;

4) initiative activities of departments and faculties.

In the first section of the Plan, it is necessary to foresee the implementation of the research work of the departments and the study of spiritual modernisation in the framework of thesis and master's theses.

The second section of the Plan should be devoted to the issues of synchronisation of the content of individual academic disciplines, primarily of a social and humanitarian orientation, with ideas of "Ruhani Zhangyru".

The third section of the Plan involves the implementation of long-term projects in which all university students and teachers will take part. The number of such projects depends on the specific conditions of each university.

The fourth section of the Plan should include activities proposed by teachers, student groups and departments. At the same time, the level of events can vary from cathedral to regional. 
In general, the success of the Programme depends on the participation of each student and teacher, regardless of their age and gender, education and profession, national and religious identity, since we are talking about universal spiritual values.

\section{Conclusion}

The presence of the Programme indicates that modern Kazakhstani society has realised the need to form a new generation of Kazakhstanis, attached to the values of spiritual revival. Thanks to this Programme, Kazakhstanis received specific strategies for changing their worldview. The mechanisms for the implementation of the Programme should be developed by the academic community, whose participation will ensure the integration of the idea of spiritual revival in the educational and research content of educational programmes.

The results of the questionnaire show the insufficient degree of formation of the universal spiritual values necessary for life in the $21^{\text {st }}$ century in most students. This means that with sufficient knowledge of the provisions of the Programme, most students have not made them part of their system of values, life goals and attitudes.

We believe that in promoting the ideas of the Programme it is important to apply conceptual, systematic, integrated approaches. Our proposed concept of promoting value-based settings of the Programme is aimed at universities and provides step-by-step planning of integrated measures. We believe that this conceptual approach will ensure the widespread involvement of students in activities related to the Programme and the measurability of the results of participation, for example, writing a graduation paper, participating in a volunteer movement, visiting sacred places in Kazakhstan, studying the Kazakh language, publishing an article about Kazakhstan in a foreign journal, preparation of a film or videos with $\mathrm{Ka}$ zakhstani content, etc. Ultimately, a balanced social portrait of a modern young Kazakhstani should be formed.

\section{References}

Chto takoe VUCA-mir i kak v nem zhit'? [What is the VUCA world and how to live in it?] (2016). Available at: https://monocler.ru/chto-takoe-vuca-mir-i-kak-v-nem-zhit/

Chukhniu, Iu. (2016). Upravlenie izmeneniami v VUCA-mire: kak vovlech' liudei i pomoch' im stat' liderami novykh reshenii [Managing change in the VUCA world: how to engage people and help them become leaders in new solutions]. In Business Excellence, 8, available at: http://novaterracoaching.su/ change-management-in-vuca/

Mir VUCA i podhody vyzhivaniya v nem [The VUCA world and its' survival approaches] (2016). Available at: http://becmology.ru/blog/management/vuca.htm

Nazarbayev, N.A. (2017). Vzglyad v budushchee: modernizatsiia obshchestvennogo soznaniia [A look into the future: the modernisation of public consciousness]. Available at: http://www.akorda.kz/ru/events/ akorda_news/press_conferences/statya-glavy-gosudarstva-vzglyad-v-budushchee-modernizaciya-obshchestvennogo-soznaniya

Nazarbayev, N.A. (2018). Sem' granei Velikoi Stepi [Seven faces of the Great Steppe]. Available at: http://www.akorda.kz/ru/events/akorda news/press conferences/statya-glavy-gosudarstva-sem-granei-velikoi-stepi

Poslanie Prezidenta Respubliki Kazahstan N.Nazarbaeva narodu Kazahstana. 14 dekabria 2012 g. [Message from the President of the Republic of Kazakhstan N. Nazarbayev to the people of Kazakhstan. December 14, 2012] (2012). Available at: http://www.akorda.kz/ru/addresses/addresses_of_president/poslanie-prezidenta-respubliki-kazahstan-nnazarbaeva-narodu-kazahstana-14-dekabrya-2012-g

Smolyaninova, O.G., Bezyzvestnykh, E.A. (2016). Razvitie politkul'turnoi kompetentnosti sovremennogo pedagoga $\mathrm{v}$ kontekste nepreryvnogo politkul'turnogo obrazovania: opyt sibirskogo regiona [The development of multicultural competence of a modern teacher in the context of continuing multicultural education: the experience of the Siberian region]. In Prepodavatel' XXI veka [Teacher of the 21 $1^{\text {st }}$ century], 
4(1), 55-76. Available at: http://ipps.sfu-kras.ru/sites/ipps.institute.sfu-kras.ru/files/publications/Prepodavatel_XXI_vek_no_4.pdf

\title{
К вопросу о духовной модернизации студенческой молодежи
}

\section{Б.А.Жетписбаева ${ }^{a}$ Ж.О. Жилбаевб,}

\section{Л.С.Сырымбетова а, Д.В.Дьякова , Л.М. Муратовав}

${ }^{a}$ Инновационный Евразийский Университет

Казахстан, Павлодар

${ }^{\sigma}$ Национальная академия образования им. И. Алтынсарина

Казахстан, Нур-Султан

${ }^{6}$ Карагандинский государственный университет имени Е.А. Букетова

Казахстан, Караганда

\begin{abstract}
Аннотация. Статья посвящена проблеме реализации национальной Программы духовного возрождения казахстанского общества. На основе эмпирических данных авторы статьи анализируют степень сформированности у студентов духовных ценностей Программы и обосновывают роль педагогического сообщества в разработке механизмов ее реализации. Авторы приходят к выводу о том, что большинство студентов информировано о положениях Программы, но не сделало их частью своей системы ценностей, жизненных целей и установок. В контексте этого авторы предлагают собственный концептуальный подход к вопросу реализации Программы в условиях вузов Казахстана.
\end{abstract}

Ключевые слова: духовное возрождение общества, модернизация сознания, ценностные установки, социальный портрет, студенты, академическое сообщество, Казахстан, казахстанец, концепция продвижения ценностей.

Научное направление: 13.00.00 - педагогические науки. 